\title{
Preface: Multifunctionality of large rivers
}

\author{
Helmut Habersack • Markus Eder • Roswitha Samek
}

Received: 31 October 2017/Revised: 30 November 2017/ Accepted: 1 December 2017/Published online: 18 January 2018 (C) Springer International Publishing AG, part of Springer Nature 2018

Rivers provide mankind with multiple goods and services, such as water, food, hydropower, navigation, irrigation, ecosystem services and recreation. They are fundamental to life and their cultural significance is of great importance. However, the pressure and impact on the World's Largest Rivers have increased greatly in recent years, as a consequence of exploitation in order to meet human needs. Large rivers are particularly exposed to problems of multiple uses, often with conflicting aims.

At a global scale, there is no overview assessment of the current status of the World's Largest Rivers, the conflicting demands for such rivers, and likely future anthropogenic impacts, as well as the potential for restoration and its associated problems.

Therefore, the first International Conference on "The Status and Future of the World's Largest

Guest editors: Helmut Habersack, Roswitha Samek \& Markus Eder / Multifunctionality of large rivers

H. Habersack · M. Eder $(\bowtie) \cdot$ R. Samek

Institute of Water Management, Hydrology and Hydraulic

Engineering, University of Natural Resources and Life

Sciences, Vienna, Austria

e-mail: markus.eder@boku.ac.at

H. Habersack

e-mail: helmut.habersack@boku.ac.at

R. Samek

e-mail: roswitha.samek@boku.ac.at
Rivers" took place in Vienna, Austria in 2011 and provided a global forum for a wide-ranging discussion of key issues related to research on large rivers and to their effective and sustainable management, involving both scientists and decision makers. This successful event has been continued in 2014 in Manaus, Brazil at the fascinating Amazon River. An international scientific committee, led by the University of Natural Resources and Life Sciences, Vienna, Austria, together with a local organizing committee, led by the Universidade Federal do Amazonas, Manaus, Brazil, organized the second conference in Manaus. Numerous scientists from all over the world presented their interesting work in various research fields such as floodplain management, aquatic ecology, ecosystem stability, sediment transport and management, measuring and modelling methods, water quality, dissolved organic and inorganic pollution.

This Special Section on "Multifunctionality of Large Rivers" in Hydrobiologia contains a selection of eight papers based on contributions to the Conference in Manaus, which provide an overview of key issues related to the hydrobiology of large river systems and demonstrate the need of further studies in this research field.

In the opening paper, Arias et al. (2016) show that the understanding and prediction of vegetation patterns in floodplains is essential for conservation and/or restoration of river floodplains. This topic is of great importance, since the technological development and 
increasing needs for energy and food in developing countries are threatening the ecosystems and biodiversity in large rivers as well as in their floodplains. Based on four case studies in Brazil, Cambodia and Botswana, Arias et al. (2016) prepared a useful summary of information about the relationship between flooding and plant species diversity in four tropical environments.

Lopes et al. (2015) deal with the responses of one of the most important species (Montrichardia arborescens) in South America's wetlands to different climatic scenarios. These responses were measured in four controlled microcosms, representing one control and three possible future climates (mild, intermediate and extreme) in terms of atmospheric $\mathrm{CO}_{2}$ concentration and air temperature.

Based on the fish survey data of the Yellow River in the 1980s and 2008, Li et al. (2015) analysed the changes of ecosystem health in this river with the Fishbased Index of Biotic Integrity (F-IBI). The authors were able to show that the river ecosystem has degraded and this was indirectly verified by variations of chemicals variables of water quality.

Schletterer et al. (2017) investigated the fish fauna of the two longest European rivers, the Volga and the Danube and presented the occurrence and a comparison of species in the two systems. Further, an innovative approach to the past and current conditions of fish and fisheries as well as the legal management framework of the two rivers is provided.

Górski et al. (2015) performed a first approach to the study of the use of marine resources by riverine populations of Galaxias maculatus (Jenyns) in Chile, across an extended latitudinal gradient and to ocean distance. Through the analysis of the concentration of $\delta 34 \mathrm{~S}$ in vertebral column tissue from fish collected in ten Chilean river systems across latitudes $36^{\circ}-47^{\circ} \mathrm{S}$, the authors detected that all fish caught in the estuary have higher values, corresponding to the use of marine resources.

Cron et al. (2015) show the need of developing a method to assess the ecological status of the heavily modified and artificial federal waterways due to the Water Framework Directive and describe the initial steps for developing it. The authors present the methodological framework and suggest additional steps that can be considered for developing an assessment tool.
Haimann et al. (2016) present a case study on the Danube River regarding the ecological optimizing of dredge and dump activities for water depth maintenance in every river harbour. The authors applied a monitoring and modelling concept on a 3-km-long Danube reach and showed the necessity of integrated monitoring and modelling approaches for harbour dredging, especially in large river systems.

Finally, Moog et al. (2015) continue to examine the effects of harbour excavating and dredged sediment disposal and present the effects on the benthic invertebrate fauna of the Danube in Austria. The authors found that the sediment dredging heavily affected the benthic invertebrates, while the dumping of the material had no effects on the benthic Danube biota.

The goal of this collection of interesting papers is to provoke new ideas, concepts and to open possibilities for new research programs worldwide. The findings of these manuscripts will bring major progress that can be used for river management and biodiversity conservation.

\section{References}

Arias, M. E., F. Wittmann, P. Parolin, M. Murray-Hudson \& T. A. Cochrane, 2016. Interactions between flooding and upland disturbance drives species diversity in large river floodplains. Hydrobiologia. https://doi.org/10.1007/ s10750-016-2664-3.

Cron, N., I. Quick \& T. Zumbroich, 2015. Assessing and predicting the hydromorphological and ecological quality of federal waterways in Germany: development of a methodological framework. Hydrobiologia. https://doi. org/10.1007/s10750-015-2484-x.

Górski, K., E. M. Habit, M. A. Pingram \& A. J. Manosalva, 2015. Variation of the use of marine resources by Galaxias maculatus in large Chilean rivers. Hydrobiologia. https:// doi.org/10.1007/s10750-015-2542-4.

Haimann, M., C. Hauer, M. Tritthart, D. Prenner, P. Leitner, O. Moog \& H. Habersack, 2016. Monitoring and modelling concept for ecological optimized harbour dredging and fine sediment disposal in large rivers. Hydrobiologia. https:// doi.org/10.1007/s10750-016-2935-z.

Li, T., X. Huang, X. Jiang \& X. Wang, 2015. Assessment of ecosystem health of the Yellow River with fish index of biotic integrity. Hydrobiologia. https://doi.org/10.1007/ s10750-015-2541-5.

Lopes, A., A. B. Ferreira, P. O. Pantoja, P. Parolin \& M. T. F. Piedade, 2015. Combined effect of elevated $\mathrm{CO}_{2}$ level and temperature on germination and initial growth of Montrichardia arborescens (L.) Schott (Araceae): a microcosm 
experiment. Hydrobiologia. https://doi.org/10.1007/ s10750-015-2598-1.

Moog, O., I. Stubauer, M. Haimann, H. Habersack \& P. Leitner, 2015. Effects of harbour excavating and dredged sediment disposal on the benthic invertebrate fauna of River Danube (Austria). Hydrobiologia. https://doi.org/10.1007/s10750015-2476-x.
Schletterer, M., V. V. Kuzovlev, Y. N. Zhenikov, J. A. Tuhtan, G. Haidvogl, T. Friedrich, K. Górski \& L. Füreder, 2017. Fish fauna and fisheries of large European rivers: examples from the Volga and the Danube. Hydrobiologia. https://doi. org/10.1007/s10750-017-3370-5. 